\title{
Open Cell Aluminum Foams Produced by Polymer Impregnation Method
}

\author{
E. ZAMAN AND Ö. KeLEŞ \\ Department of Metallurgical and Materials Engineering, Istanbul Technical University \\ 34469 Maslak, Istanbul, Turkey
}

\begin{abstract}
In this study, open cell aluminum foams were produced using the polymer impregnating method. This method consists of slurry preparation, template coating, drying, burning and finally sintering. Physical properties of the open cell aluminum foams were characterized. Microstructures were investigated utilizing optical and scanning electron microscopy. $\mathrm{Cu} K_{\alpha}$ was used as X-ray source in phase analysis. The hardness of the foams was measured by applying Vickers hardness test. An ideal foam coating was achieved using the slurry having $60 \%$ solid content mixed with a speed of $1000 \mathrm{rpm}$ for $3 \mathrm{~h}$. The polyurethane foam was burned out at $500{ }^{\circ} \mathrm{C}$ and ideal sintering parameters were $620^{\circ} \mathrm{C}$ for 4 or $7 \mathrm{~h}$. The foam densities containing $60 \%$ solid were found to be $0.12-0.15 \mathrm{~g} / \mathrm{cm}^{3}$. The porosity values were calculated to be in the range of $94.4-95.5 \%$. Micro hardness values were $30.3-34.7 \mathrm{Hv}$.
\end{abstract}

DOI: $10.12693 /$ APhysPolA.125.445

PACS: 82.70.Rr

\section{Introduction}

Open cell foams have received a great deal of attention due to their wide application areas such as heat exchangers, filters, sound insulations, catalyst carriers, flame arrestors, and silencers where high thermal conductivity, high liquid/gas permeability, and insulation are needed $[1,2]$. There are a variety of methods to produce open cell aluminum foams such as investment casting, casting around hollow spheres, metal injection molding, space holder, and polymer impregnation, etc. Among these, polymer impregnation method has advantages of practicality, controllable pore size $[3,4]$.

In this process polymeric foam was used as a template. Polyvinyl alcohol, aluminum powders were mixed with distilled water to form the thixotropic slurry. Polymeric foam was impregnated into slurry. After drying process, the polymeric foam was burned out and the metallic body was sintered.

Recently, polymer impregnation method has been used in the production of open cell ceramic [5-7], titanium [8-10], $\mathrm{TiH}_{2}[11,12]$ and $\mathrm{Ti6Al4V}[13,14]$ foams. In 2009, this method has been utilized by Michailidis et al. to produce open cell aluminum foam [15].

The aim of this study is to produce open cell aluminum foams using polymeric impregnation method. It is known that open cell aluminum foams could be produced by using polymeric impregnation method. This study is focused on determination of slurry recipe for having an open cell aluminum foams.

Within the scope of this study, four different slurries, containing $51 \%, 54 \%, 56 \%$, and $60 \%$ solid contents, were prepared. PU templates having 25 and 40 ppi (pores per inch) were dipped into these slurries and the coated templates were dried. Then, the coated templates were subjected to a series heating processes to produce open cell aluminum foams.
Sedimentation tests were applied to investigate the effect of solid content on slurry rheology. The densities of the cells were determined using the Archimedes principle. The pore morphology were characterized by using scanning electron microscopy (SEM). Lastly, micro hardness measurements were conducted to determine the mechanical properties of aluminum foams.

\section{Experimental procedure}

\subsection{Materials}

The materials include: aluminum powder having the average particle sizes of $15 \mu \mathrm{m}$, polyvinyl alcohol (PVAL), polyurethane foams (PU), and distilled water. As a binder water soluble Mowiol 5/88 was used. The powders were atomized spheroidal in shape with $99.5 \%$ purity (Alfa Aesar of Japan). Open cell PU foams with 25 and 40 ppi were used as template.

\subsection{Preparation of open cell aluminum foams}

Polyvinyl alcohol was dissolved in distilled water at $95^{\circ} \mathrm{C}$ for one hour. Aluminum powder was added into the mixture and the mixture was stirred with magnetic stirrer $\left(30 \times 6 \mathrm{~mm}^{2}\right)$ with a stirring rate of $1000 \mathrm{rpm}$ for $2 \mathrm{~h}$. The slurries with $51 \%, 54 \%, 56 \%$, and $60 \%$ solid loading were prepared as seen in Table I. Polyurethane foams (25 and $40 \mathrm{ppi}$ ) were cut into rectangular blocks of approximately $10 \times 10 \times 10 \mathrm{~mm}^{3}$ and $20 \times 10 \times 10 \mathrm{~mm}^{3}$. This foam samples were dipped into the slurries and compressed for 20 min. Excess slurry was removed and polyurethane foams were coated. Then, samples were dried for $24 \mathrm{~h}$ at room temperature and subsequently the samples were put in a drying oven for $6 \mathrm{~h}$ at $100^{\circ} \mathrm{C}$. Finally, the samples were slowly heated from room temperature to $500^{\circ} \mathrm{C}$ for $2 \mathrm{~h}$ to burn out the PU foams and ultimately sintered at $620^{\circ} \mathrm{C}$ for 4 and $7 \mathrm{~h}$ in air. 
TABLE I

Slurry composition vs. viscosity values and amount of settled material in a measuring cylinder at the end of 0 min, $30 \mathrm{~min}, 3 \mathrm{~h}$, and $24 \mathrm{~h}$.

\begin{tabular}{|c|c|c|c|c|c|c|c|c|c|}
\hline \multirow{2}{*}{$\begin{array}{l}\text { Slurry } \\
\text { no. }\end{array}$} & \multirow{2}{*}{$\begin{array}{c}\text { Distilled } \\
\text { water [ml] }\end{array}$} & \multirow{2}{*}{$\begin{array}{c}\text { Al powder } \\
{[\mathrm{g}]}\end{array}$} & \multirow{2}{*}{$\begin{array}{l}\text { PVAL } \\
\text { [g] }\end{array}$} & \multicolumn{4}{|c|}{ Amount of settled material [ml] } & \multirow{2}{*}{$\begin{array}{c}\text { Solid } \\
\text { content [\%] }\end{array}$} & \multirow{2}{*}{$\begin{array}{c}\text { Viscosity } \\
\quad\left(C_{p}\right)\end{array}$} \\
\hline & & & & $0 \min$ & $30 \mathrm{~min}$ & $3 \mathrm{~h}$ & $24 \mathrm{~h}$ & & \\
\hline 1 & 50 & 46 & \multirow{4}{*}{6} & \multirow{4}{*}{0} & 0.5 & 0.5 & 1.5 & 51 & 400 \\
\hline 2 & 45 & 46 & & & 0 & 0.1 & 1.0 & 54 & 3461 \\
\hline 3 & 50 & 60 & & & 0 & 0.5 & 1.0 & 56 & 6432 \\
\hline 4 & 50 & 70 & & & 0 & 0 & 0.6 & 60 & 10263 \\
\hline
\end{tabular}

\subsection{Characterization of slurries prepared and the open cell aluminum foams}

The influence of solid content on rheological behaviors such as sedimentation and viscosity were investigated. For sedimentation test the slurries with $51 \%, 54 \%, 56 \%$, and $60 \%$ solid contents were placed in a $10 \mathrm{ml}$ measuring cylinder and allowed to settle in a measuring cylinder for $0 \mathrm{~min}, 30 \mathrm{~min}, 3 \mathrm{~h}$ and $24 \mathrm{~h}$. Viscosities of slurries with $51 \%, 54 \%, 56 \%$, and $60 \%$ solid contents were measured in a Brookfield DV-2 viscometer with a SC 14 spindle at room temperature.

Densities of the foams were measured by utilizing the Archimedes principle and the porosity levels of the samples were calculated. The foams were filled and coated with resin. Then, they were grinded (240, 320, 600, $800,1200,2500$ mesh $)$ and polished $(3 \mu \mathrm{m}, 1 \mu \mathrm{m} \mathrm{di}-$ amond paste) for microstructural invesitigations. The microstructural characterization of the foam was made by using Leica DMRX optical microscope and JEOL JSM 5410 scanning electron microscope. XRD analysis was conducted using Rigaku Miniflex $\left(\mathrm{Cu} K_{\alpha}\right.$ radiation, $30 \mathrm{kV}-15 \mathrm{~mA}, 3^{\circ} / \mathrm{min}, 10-70^{\circ}$ ) to determine phase structure after sintering. Lastly, micro hardness measurements were conducted on polished samples. Vickers hardness with a load of $25 \mathrm{gf}$ and a holding time of $12 \mathrm{~s}$ was measured at various locations of the polished foam samples.

\section{Results and discussion}

Figure 1 shows the effect of solid contents on the viscosities of the slurries. Increasing solid content tends to increase the viscosity. The slurry having $60 \%$ solid content exhibits the most viscous slurry and the slurry with $51 \%$ solid content exhibits the least viscous slurry as expected. Three experiments were made to show the reproducible.

In Table I, viscosity values and amount of settled material in a measuring cylinder at the end of $0 \mathrm{~min}, 30 \mathrm{~min}$, $3 \mathrm{~h}$ and $24 \mathrm{~h}$ are given. Sure enough, viscosity increased with increasing solid content.

Cachinho et al. proposed that particles are exposed to attractive Van der Waals forces in a suspension. At low solid contents, the magnitude of these forces between particles is weak due to the relatively large interparticle distance. With increasing solid contents, interparticle distance is getting closer and Van der Waals forces between particles are getting strong [12]. For this reason,

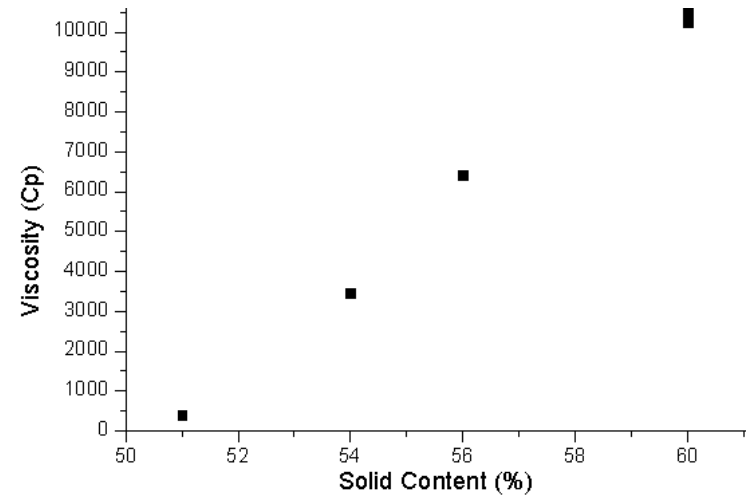

Fig. 1. Viscosity and solid content ratios of aluminum slurries.

among four slurries, the first slurry having minimum solid content $(51 \%)$, has the weakest Van der Waals forces between particles and it has the highest sediment speed at the end of $24 \mathrm{~h}$. The fourth slurry having $60 \%$ solid content has the strongest Van der Waals forces among particles and it shows the lowest sediment speed at the end of $24 \mathrm{~h}$ (see Table I). The first slurry was not viscous enough that the polyurethane foam's struts were coated with limited amount of aluminum. Second and third slurries were more viscous than the first slurry but in these cases also homogeneous coatings of the struts were not observed. Hence, aluminum slurry did not take the shape of polyurethane foam after the polyurethane foam was burned out. PU foam's struts were coated uniformly in case of the fourth slurry recipe. The shape of polyurethane foam after the PU foam was burned out was maintained. Thus, it was decided that the slurry prepared, having $60 \%$ solid content (70 g Al, $50 \mathrm{ml}$ distilled water and $6 \mathrm{~g}$ PVAL) and with $1000 \mathrm{rpm}$ stirring rate, provided an optimum rheology for coating PU template.

Figure 2 shows the open cell aluminum foams produced by slurry method with optimum slurry recipe in the experiments. As expected the macro porosity sizes of open cell aluminum foams which are produced with $25 \mathrm{ppi}$ polyurethane foams were greater than the macro porosity sizes of open cell aluminum foams that are produced with 40 ppi polyurethane foams.

The densities and porosities of open cell aluminum foams containing $60 \%$ solid content are shown in Table II. The densities of open cell aluminum foams range between 


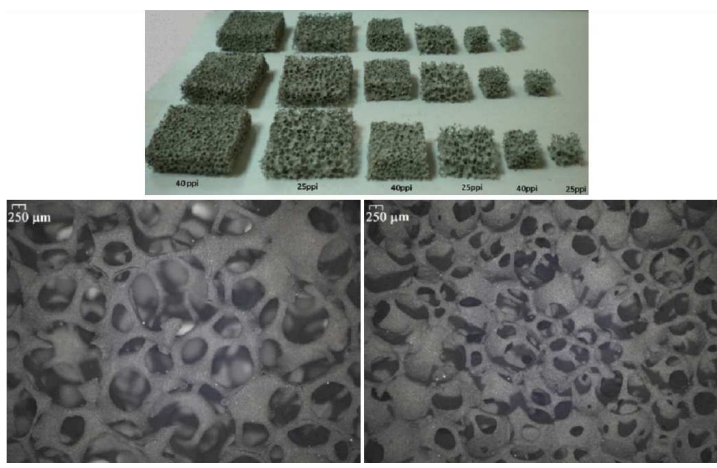

Fig. 2. (top) The open cell aluminum foams produced with $60 \%$ solid content slurry by slurry method in the experiments. (left) The open cell aluminum foams having 25 ppi. (right) The open cell aluminum foams having 40 ppi.

TABLE II

The densities and porosities of open cell aluminum foams produced using $60 \%$ solid content.

\begin{tabular}{c|c|c|c}
\hline \hline $\begin{array}{c}\text { Polyurethane } \\
\text { foam porosity } \\
{[\mathrm{ppi}]}\end{array}$ & $\begin{array}{c}\text { Sintering } \\
\text { time } \\
{[\mathrm{h}]}\end{array}$ & $\begin{array}{c}d \\
{\left[\mathrm{~g} / \mathrm{cm}^{3}\right]}\end{array}$ & $\begin{array}{c}\text { Porosity } \\
{[\%]}\end{array}$ \\
\hline 25 & 4 & $0.12 \pm 0.01$ & $95.5 \pm 0.26$ \\
25 & 7 & $0.14 \pm 0.01$ & $94.8 \pm 0.14$ \\
40 & 4 & $0.12 \pm 0.01$ & $95.5 \pm 0.13$ \\
40 & 7 & $0.15 \pm 0.01$ & $94.4 \pm 0.25$
\end{tabular}

$0.12 \pm 0.01-0.15 \pm 0.01 \mathrm{~g} / \mathrm{cm}^{3}$. The density of aluminum foams varied from 0.1 to $0.4 \mathrm{~g} / \mathrm{cm}^{3}$ when liquid metal methods are used [16]. However, this value yields to $0.3-1 \mathrm{~g} / \mathrm{cm}^{3}$ when powder methods are utilized. It is noteworthy to remind that by the nature of polymer impregnation method, there is no pressure applied unlike the other powder methods. Thus, the foam samples might have had micro porosities and they could not have a dense structure. Hence, they might have had similar density values with the products, which were produced by liquid metal methods.

As seen in Table II, sintering time and the pores size of polyurethane foam did not affect the porosity of open cell aluminum foams significantly.

Pores, which are enclosed with aluminum are called macro pores. Aluminum bridge located between two macro pores is called strut and among three macro pores is called cell edge. Optical and SEM image of macro pores and struts are seen in Figs. $3 a$ and b, respectively. Cell edge is also seen in SEM image in Fig. 3b.

The XRD pattern of open cell aluminum foam (40 ppi polyurethane foam) after sintering at $620^{\circ} \mathrm{C}$ for $7 \mathrm{~h}$ in air is shown in Fig. 4. Aluminum oxide was not present and XRD results showed that open cell aluminum foam associated with the cubic aluminum phase.

The micro hardness values were revealed that open cell aluminum foams $(30.3 \pm 3.15-34.7 \pm 7.27 \mathrm{Hv})$ were nearly

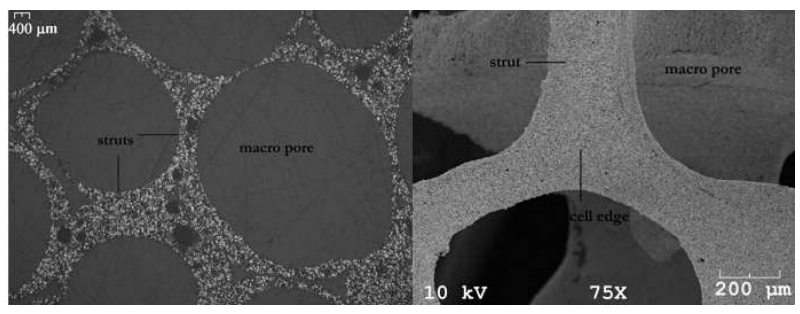

Fig. 3. (left) Optical image of open cell aluminum foam (40 ppi) sintered for $4 \mathrm{~h}$, (right) SEM image of open cell aluminum foam (25 ppi) sintered for $7 \mathrm{~h}$.

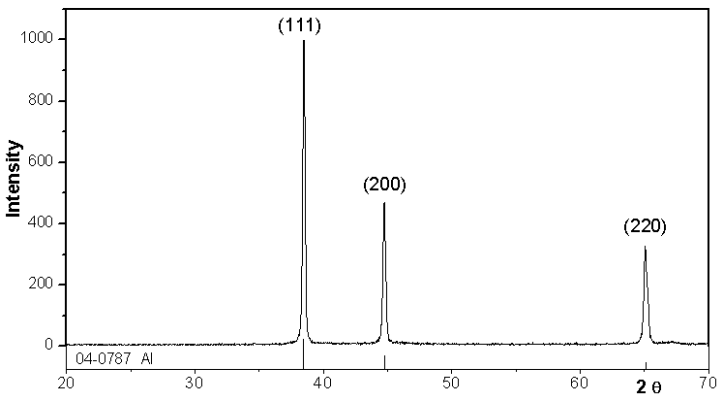

Fig. 4. XRD patterns of the open cell aluminum foam (40 ppi) sintered at $620^{\circ} \mathrm{C}$ for $7 \mathrm{~h}$ in air.

as strong as ERG Company's [17] open cell aluminum foams $(35 \mathrm{Hv})$ which are produced by investment casting and Alporas Company's closed cell aluminum foams $(30.5 \mathrm{Hv})$ which are produced by gas releasing particle decomposition in melt. Also the micro hardness values of open cell aluminum foams are less than Alulight Company's closed cell aluminum foams $(54.8 \mathrm{Hv})$ which are produced by powder metallurgy [18].

\section{Conclusions}

Open cell aluminum foams were produced using 25 and 40 ppi polyurethane foams by polymer impregnation method. An open cell aluminum foam was produced with $60 \%$ solid content $(50 \mathrm{ml}$ distilled water, $6 \mathrm{~g}$ PVAL, $70 \mathrm{~g}$ aluminum). This slurry was mixed with a speed of $1000 \mathrm{rpm}$ for $3 \mathrm{~h}$. The sintering process was found to play a critical role in forming the open cell aluminum foams. The ideal heat treatment process parameters were determined to be $500{ }^{\circ} \mathrm{C}$ to burn the polymeric foam and subsequently sintering was conducted at $620^{\circ} \mathrm{C}$ for 4 or $7 \mathrm{~h}$. The sintering time had no significant affect on the foam density and porosity level. The densities and porosity levels were found to be in the range of $0.12-0.15 \mathrm{~g} / \mathrm{cm}^{3}$ and $94.4-95.5 \%$, respectively. The micro hardness values were varied between $30.3-34.7 \mathrm{Hv}$.

\section{Acknowledgments}

The authors are grateful for the financial support of Scientific Research Project Office of Istanbul Technical University (ITU) for this project. 


\section{References}

[1] M.F. Ashby, A.G. Evans, N.A. Fleck, L.J. Gibson, J.W. Hutchinson, H.N.G. Wadley, Metal Foams A Design Guide, Elsevier Sci., USA 2000, p. 3, 44.

[2] K.S. Chou, M.A. Song, Scr. Mater. 46, 379 (2002).

[3] L. Montanaro, Y. Jorand, G. Fantozzi, A. Negro, J. Eur. Ceram. Soc. 18, 1339 (1998).

[4] J. Luyten, S. Mullens, J. Cooymans, A.M. De Wilde, I. Thijs, R. Kemps, J. Eur. Ceram. Soc. 29, 829 (2008).

[5] M.A. Nor, L.C. Hong, Z.A. Ahmad, H.M. Akil, J. Mater. Proces. Technol. 207, 235 (2008).

[6] M. Dressler, S. Reinsch, R. Schadrack, S. Benemann, J. Eur. Ceram. Soc. 29, 3333 (2009).

[7] K. Lemster, M. Delporte, M. Granule, T. Kueber, Ceram. Inter. 33, 1179 (2006).

[8] S.C.P. Cachinho, R.N. Correia, J. Mater. Sci., Mater. Med. 19, 451 (2008).

[9] J. Zhao, X. Lu, J. Weng, Mater. Lett. 62, 2921 (2008).
[10] S. Ahmad, N. Muhamad, A. Muchtar, J. Sahari, K.R. Jamaludin, N.H.M. Nor, Int. J. Mech. Mat. Eng. 5, 244 (2010).

[11] J.H. Lee, H. Kim, Y.H. Koh, Mater. Lett. 63, 1995 (2009).

[12] S.C.P Cachinho, R.N. Correia, Powder Technol. 178, 109 (2007).

[13] J.P. Li, C.A.V. Blitterswijk, K. Groot, J. Mater. Sci., Mater. Med. 15, 951 (2004).

[14] J.P. Li, C.A.V. Blitterswijk, K. Groot, J. Biomed. Mater. Res. A 2, 223 (2005).

[15] N. Michailidis, F. Stergioudi, H. Omar, D.N. Tsipas, Mech. Mater. 42, 142 (2009).

[16] J. Banhart, Europhys. News 30, 17 (1999).

[17] CEC, 2011, http://www.ergaerospace.com/ Aluminum-properties .htm (2012).

[18] M.I. Idris, T. Vodenitcharova, M. Hoffman, Mater Sci. Eng. A 517, 37 (2009). 